\title{
The effectiveness of endozoochory in three avian seed predators
}

\author{
Grzegorz Orłowski ${ }^{1} \cdot$ Joanna Czarnecka $^{2} \cdot$ Artur Goławski $^{3} \cdot$ Jerzy Karg $^{4} \cdot$ \\ Marek Panek ${ }^{5}$
}

Received: 4 January 2015/Revised: 20 May 2015/Accepted: 28 May 2015/Published online: 10 June 2015

(C) The Author(s) 2015. This article is published with open access at Springerlink.com

\begin{abstract}
The role of granivorous birds as agents of seed dispersal has been little explored and is poorly understood. We assessed the ability of three species of birds from a Central European agricultural landscape to disperse seeds of dry-fruited plants. We hypothesised that Grey Partridge Perdix perdix is a better seed disperser than either of two species of buntings-Yellowhammer Emberiza citrinella and Reed Bunting Emberiza schoeniclus-in terms of the number of intact seeds recovered from their droppings. Partridge droppings contained the highest number of intact seeds. Surprisingly, however, the number of intact seeds per $1 \mathrm{~g}$ of droppings was the highest in Reed Bunting, smaller in Grey Partridge and the smallest in Yellowhammer. Our findings suggest that the passage of intact seeds of dryfruited plants through the digestive tract of seed-eating birds is most likely an effect of limited digestion, resulting from the intake of a large volume of seeds, a small part of which
\end{abstract}

Communicated by F. Bairlein.

Grzegorz Orłowski

orlog@poczta.onet.pl

1 Institute of Agricultural and Forest Environment, Polish Academy of Sciences, Bukowska 19, 60-809 Poznań, Poland

2 Ecology Department, Institute of Biology and Biochemistry, Maria Curie-Skłodowska University, Akademicka 19, 20-033 Lublin, Poland

3 Department of Zoology, Faculty of Natural Science, Siedlce University of Natural Sciences and Humanities, Prusa 12, 08-110 Siedlce, Poland

4 Department of Nature Conservation, Faculty of Biological Sciences, University of Zielona Góra, Prof. Z. Szafrana 1, 65-516 Zielona Góra, Poland

5 Polish Hunting Association, Research Station, Sokolnicza 12, 64-020 Czempiń, Poland remains undigested. This effect could be magnified by the inclusion in the diet of some items of different digestibility (invertebrates or leaves). We suggest that non-standard dispersal of seeds with no adaptations to endozoochory by birds is a far more frequent and as yet under-appreciated phenomenon, which has potential ecological implications for the colonisation of new habitats/islands by plants. The ultimate elucidation of this process is extremely difficult and would require large sets of faeces to be examined.

Keywords Seed predators - Seed dispersal - Granivores · Bird droppings · Intact seeds · Unassisted dispersal

\section{Zusammenfassung}

Effektivität von Endozoochorie bei drei körnerfressenden Vogelarten

Die Rolle körnerfressender Vögel als Verbreiter von Pflanzensamen ist bislang nur wenig untersucht worden und wird dementsprechend auch noch wenig verstanden. Für drei Vogelarten einer landwirtschaftlich genutzten Region in Zentraleuropa untersuchten wir ihre Fähigkeit, die Samen von Trockenfrüchten zu verbreiten. Unsere Hypothese war, dass Rebhühner (Perdix perdix) wirksamere Samenverbreiter sind als die beiden Ammer-Arten Goldammer (Emerbiza citrinella) und Rohrammer (Emberiza schoeniclus); dies wurde aus der Anzahl noch intakter Samen im Kot der Vögel ermittelt. Zwar enthielt der Kot der Rebhühner die größte Anzahl intakter Samen, überraschenderweise war aber der Anteil intakter Samen pro Gramm Kot bei der Rohrammer am größten, beim Rebhuhn etwas kleiner und am kleinsten bei der Goldammer. Unsere Ergebnisse deuten darauf hin, dass der Durchmarsch intakter Samen durch den Verdauungstrakt 
körnerfressender Vögel höchstwahrscheinlich an mangelhafter Verdauung liegt, hervorgerufen durch die Aufnahme großer Mengen an Samenkörnern, von denen dann ein bestimmter, kleiner Anteil unverdaut bleibt. Dieser Effekt könnte noch durch die Aufnahme anderer Nahrungsbestandteile, die unterschiedlich verdaut werden (Wirbellose, oder Blätter), vergrößert werden. Wir denken, dass die ungewöhnliche Verbreitung von Samen durch Vögel ohne Anpassung an Endozoochorie viel häufiger ist und bisher unterschätzt wurde und dass sie ein ökologisches Potential für die Pflanzen-Besiedlung neuer Gegenden/Inseln durch Vögel bietet. Eine endgültige Aufklärung dieses Prozesses wäre allerdings außerordentlich schwierig und würde große Mengen an zu prüfendem Kot erfordern.

\section{Introduction}

Seed dispersal mechanisms are crucial to many ecological processes. An appreciation of them helps us to acquire a better understanding of the factors responsible for plant population dynamics and community structure, gene flow, metapopulation dynamics, evolutionary trade-offs and maintenance of biodiversity (Schupp 1993; Schupp et al. 2010). Seed dispersal and seed digestion used to be treated as separate processes. Since seeds are destroyed during digestion, granivorous animals are thought to play little or no role in the dispersal of plants (Hulme 2002). Now, however, it is thought that for avian granivores, a continuum exists between seed dispersal and seed predation (Heleno et al. 2010). Importantly, the idea that seed predators could disperse seeds was formulated much earlier during extensive studies of scatter-hoarding rodents, corvids and primates, which can disperse seeds or fruits, mostly the seeds of conifers and nuts of broadleaved trees, but also the seeds of grasses and forbs (cf. Vander Wall 1990, 2010 and literature cited therein; Norconk et al. 1998). Propagules overlooked by the hoarder, and which can also escape detection by other animals, can germinate successfully (Vander Wall 1990, 2010; Zwolak and Crone 2011; Lenda et al. 2012).

The effectiveness of the dispersal (the term suggested by Schupp 1993 and revisited in Schupp et al. 2010) a plant receives from granivorous animals is usually evaluated as very low, because of the low probability of seeds being dispersed (quantity of seeds dispersed) and the poor quality of seed treatment (quality of dispersal). However, some studies have shown that granivorous birds can be legitimate vectors for the dispersal of the seeds of dry-fruited species without a fleshy pulp, which is thought to be an adaptation to endozoochory (Guerrero and Tye 2009; Heleno et al. 2010, 2013; Nogales et al. 2012).
To date, there have been few studies quantifying the role of granivorous birds in seed dispersal; such investigations are especially needed to broaden the knowledge about patterns and components of dispersal effectiveness in different habitats (Heleno et al. 2010, 2013; Nogales et al. 2012; Gillespie et al. 2012). In general, granivorous species consume, crush and digest the vast majority of ingested seeds (Norconk et al. 1998; D'hondt and Hoffman 2011); however, in the global context and considering the magnitude of seed production in some ecosystems (Marone et al. 2000; Evans et al. 2011) and the abundance of granivorous birds, even the small fraction of plant propagules that escape digestion can be important for colonising new and distant sites (Nogales et al. 2012). Hence, quantification of the effectiveness of dispersal by different granivorous animals across various spatial scales and/or habitats undoubtedly provides an important insight into this poorly known process and can be helpful in explaining plant dispersal mechanisms (Schönswetter et al. 2008; Heleno et al. 2010; Gillespie et al. 2012; Nogales et al. 2012).

Although interest in the assessment of birds as potential dispersers of dry-fruited or weed seeds has a long history (cf. Roessler 1936), comprehensive studies of the abundance of intact seeds in the droppings of seed-eating birds are scarce. To the best of our knowledge, only a few studies have quantified the presence of intact seeds in faecal samples in direct observations of 14 granivorous bird species. These include studies of nine species of endemic Galapagos finches Geospiza spp. (Buddenhagen and Jewel 2006; Guerrero and Tye 2009; Heleno et al. 2013), four species of small Eurasian granivorous Passerines in the Azores (Heleno et al. 2010) and one medium-sized gamebird, the Grey Partridge Perdix perdix, in crop fields of continental Europe (Orłowski and Czarnecka 2013). All these studies showed that granivorous birds defecate intact seeds-primarily of fleshy-fruited species in the case of birds from the Galapagos, the Azores and North America. For smaller granivores, with the exception of Grey Partridge study, none of the studies linked the presence of intact seeds in droppings to the dietary composition or habitat types used as feeding sites. This is because sample sizes were often too small to assess (or exclude) some small granivorous birds as potential vectors of seed dispersal (e.g., Buddenhagen and Jewel 2006). In addition, the dispersal of endozoochorous seeds, including the dispersal of non-endozoochorous dry-fruited plants, has been assessed for large, omnivorous species (Emu Dromaius novaehollandiae (Calviño-Cancela et al. 2006) and Cassowary Casuarius casuarius johnsonii (Bradford and Westcott 2011)) and for the medium-sized Rook Corvus frugilegus, whose regurgitated pellets were analysed; Czarnecka and Kitowski (2010, 2013), Czarnecka et al. (2013a, b). 
Considerably more avian studies have focussed on the endozoochorous dispersal of seeds of fleshy-fruited plants, including studies with species recognised as seed predators, for instance, the large galliform species, Northern Bobwhite Tetrao virginianus (cf. Cipollini and Levey 1997 and references therein).

Within the framework described above, we assessed the seed-dispersing ability of three species with different body masses and seed-processing methods feeding in similar habitats. We hypothesised that the larger-bodied seed predator ingesting whole seeds (Grey Partridge Perdix perdix, ca. 400 g) would be a better seed disperser (transporting a larger number of seeds) than two smaller bunting species, which crush the seeds with their bills before swallowing them (Yellowhammer Emberiza citrinella, ca. 30 g; Reed Bunting E. schoeniclus, ca. 19 g). All three species make up a considerable percentage of the autumn-winter community of avian granivores feeding on/using crop fields in Europe (Moorcroft et al. 2002; Orłowski 2006; Kasprzykowski and Goławski 2012), and their diets consist primarily of seeds of various arable weeds (Cramp 1998; Holland et al. 2006; Orłowski and Czarnecka 2007; Orłowski et al. 2011, 2014). Therefore, an assessment of the contribution to ecosystem services provided by these birds, in the context of weed seed predation/dispersal or the seasonal depletion of seed resources as a result of consumption (sensu Pinowski and Wójcik 1968; Robinson and Sutherland 2000; Marone et al. 2000; Holmes and Froud-Williams 2005), is highly desirable. Such an approach to ecological studies is strongly advocated nowadays (cf. Sekercioglu 2006; Wenny et al. 2011), especially in the context of the observed dramatic declines in seed-eating bird populations because of agricultural intensification (Panek 2005; Butler et al. 2010; PECMBS 2011), and the resulting overall decline of ecological services provided by birds (Sekercioglu 2006; Wenny et al. 2011). In this work we analyse the structure of the seed pool present in faecal samples of these three granivores; special attention is paid to the habitat used as the feeding site and the features of seeds that enhance the probability of surviving ingestion. These features of seeds are similar to those needed to create a persistent soil seed bank, i.e., a low mass ( $<3 \mathrm{mg}$ ) and compact shape (Thompson et al. 1993; Pakeman et al. 2002). Furthermore, we hypothesised that the total number of intact seeds and the probability of the recovery of at least one intact seed in the faecal samples would be related to the amount of droppings expressed as their total number or total weight. We assumed that the amount of droppings is likely to be related directly to the total volume or biomass of ingested plant food, both within and among the three target species.

\section{Materials and methods}

\section{Study sites}

The study was conducted in a lowland agricultural landscape in Poland. The area is characterised by a temperate continental climate with a large temperature amplitude between summer, June-September (high; monthly average $+15{ }^{\circ} \mathrm{C}$ ), and winter, December-February (low; $<0{ }^{\circ} \mathrm{C}$ ). Droppings were sampled during autumn and winter (November-February) between 2002 and 2013 in various habitat types typical of the agricultural landscapes of central Europe that serve as feeding grounds and nocturnal roosts for the three target granivorous birds: winter crop fields (cereals and oil-seed rape), stubble fields (including fields left unploughed following maize cultivation and abandoned grasslands), ploughed fields (with no vegetation), meadows (on wetland sites), fallow land (including land not farmed for several years at least and now covered by permanent vegetation) and manure heaps (sites where various amounts of pig and cattle manure are periodically stored). The flora of the sample sites was diverse, although weed communities characteristic of each cultivation type were present. Geranium dissectum, Galinsoga parviflora, Galinsoga ciliata and Stellaria media occurred in low densities in the winter cereal and winter oil-seed rape fields; Amaranthus retroflexus, Chenopodium album, Setaria viridis and Polygonum aviculare were present in high densities in the stubble fields.

\section{Sample collection and processing}

We collected droppings from 79 feeding or roosting sites (hereafter, one site is treated as a single sample): 36 samples (1162 droppings) of Grey Partridge faeces, 17 samples (999 droppings) from Reed Buntings and 26 samples (624 droppings) from Yellowhammers (Appendix Table 3). In the case of the two buntings, droppings were collected after direct observation of birds defecating so as to prevent misidentification. As partridge droppings are very characteristic, we were able to recognise and collect them directly from the ground, even if no bird had been observed before. Prior to the collection of some droppings on private land we obtained permission from the owners of some fields; some droppings were collected from public places (such as road verges). All the droppings analysed in this study were collected during earlier field studies aimed at determining the dietary composition of the three target bird species; more details of the specific location of the study of individual species will be found in the references cited below. The droppings were dried, weighed and stored at $20{ }^{\circ} \mathrm{C}$ until analysis. To evaluate the dietary composition and 
presence of seeds/dry fruits (hereafter, the term "seed" will be used to refer to both seeds and dry fruits), all the Reed Bunting droppings were analysed (results published in Orłowski and Czarnecka 2007; Orłowski et al. 2013). In the case of Grey Partridge $0.5 \mathrm{~g}$ (ca. 4 droppings) from each sample and in the case of Yellowhammer $0.2 \mathrm{~g}$ (ca. 10 droppings) were analysed to evaluate the dietary composition of the faecal sample per site.

Each dropping was first examined to exclude intact seeds stuck to its surface. The droppings were then manually crushed in petri dishes containing water and examined at $\times 40$ magnification. Methods of diet analysis are described in Orłowski and Czarnecka (2007), Orłowski et al. (2011) and Orłowski et al. (2014). The proportion of all identifiable diet items was assessed and both intact (no traces of external damage) and damaged seeds (seed shell damaged, but seed not broken up) were counted. The seeds recovered from the droppings were identified to the lowest possible taxonomic level. Atlases (Cappers et al. 2006; Bojňanský and Fargašová 2007) and seed collections were used to identify the seed species. We determined the relative dietary composition (on the basis of the number of food remains found in the faecal samples) of each faecal sample using four classes of abundance [0-absence, $1-$ sporadic items (proportion $<1 \%$ ), 2 -items of medium abundance (proportion 1-40\%), 3-dominant items; proportion $>40 \%$; usually $90 \%$ or more; only when items with medium abundance were present in the same sample was their proportion lower] for each of five main food categories: (1) leaf fragments, (2) seeds represented by shell fragments, (3) grains represented by fragments of cereal grains, (4) husks of wild grasses and (5) animal prey items (Appendix Table 3).

\section{Data analysis}

For each faecal sample $(N=79)$, the number of intact seeds was expressed per ten droppings and $1 \mathrm{~g}$ of faeces. Initially, these two measures, along with the mean mass of individual droppings, were compared among the three species using the generalised linear model (GLM) with the Poisson error distribution and logarithmic link function in Statistica 7.1 (Statsoft 2007).

Further, we applied regression analysis in GLM in Statistica 7.1 (Statsoft 2007) to assess the relationship between the number of intact seeds in faecal samples and the number of droppings expressed as a whole number and the log-transformed total weight of a faecal sample. To assess the probability of recovering at least one intact seed from a faecal sample we applied logistic regression (Statsoft 2007). The presence (1) or absence (0) of intact seeds in a sample was treated as the dependent variable, with the independent variables being the number and log- transformed total weight of droppings in a sample from one species. We performed the above analyses for each target species separately. However, to generalise our findings by detecting analogous relationships across the community of granivores we performed an overall GLM and logistic regression model, pooling the data for all species and introducing "bird species" as a random effect in the statistical analysis.

As a measure of dietary diversity we used the number of wild plant taxa other than cereals (for the list, see Appendix Table 4) that were identified in the diet. The correlation between these values and the number of intact seeds present in the sample was measured using the Spearman rank correlation coefficient.

A detrended component analysis (DCA) was conducted to analyse the potential relationship between dietary composition (see above) and the presence of intact seeds in faecal samples $(N=79)$ using MVSP (Kovach 2005) and Statistica 7.1. The data used for DCA are presented in Appendix Table 4.

The statistical significance was set at $p \leq 0.05$.

Seed shape as a variance of the three dimensions of a seed (length, width and depth) is used to evaluate whether the shape of a seed is compact (close to spherical). It can take a minimum value of zero when the seed is spherical and a maximum value of ca. 0.3 for needle- or disc-shaped seeds (Thompson et al. 1993).

\section{Results}

The average mass of droppings varied with the size of the target species: droppings of Reed Buntings and Yellowhammers were 6 and 12 times lighter respectively than those of Grey Partridges (Fig. 1a).

Intact seeds were present in $44 \%(16 / 36)$ of Grey Partridge faecal samples, in $35 \%(6 / 17)$ of Reed Bunting faecal samples and in $19 \%(5 / 26)$ in Yellowhammer faecal samples (Appendix Table 3). The seeds recovered (from 13 different plant families) were from 20 (Grey Partridge), 6 (Reed Bunting) and 3 taxa (Yellowhammer) (Table 1). None of the 218 intact seeds found were obviously adapted to endozoochory (cf. Table 1 for the description of types of seed dispersal). The most frequent groups were anemochores $(48.1 \%$ of all seeds found; dominated by smallseeded species such as Capsella bursa-pastoris and Gypsophila muralis), followed by barochores (43.6\%), epizoochores $(7.8 \%)$ and hydrochores $(0.5 \%)$. All seeds found in faeces were small (seed mass $<3 \mathrm{mg}$ ) and the majority of them had a compact shape (except for the longer cypselas of Artemisia vulgaris, Galinsoga parviflora/ciliata, Senecio sp. and grains of Echinochloa crusgalli and Poa апnиа; Table 1). 

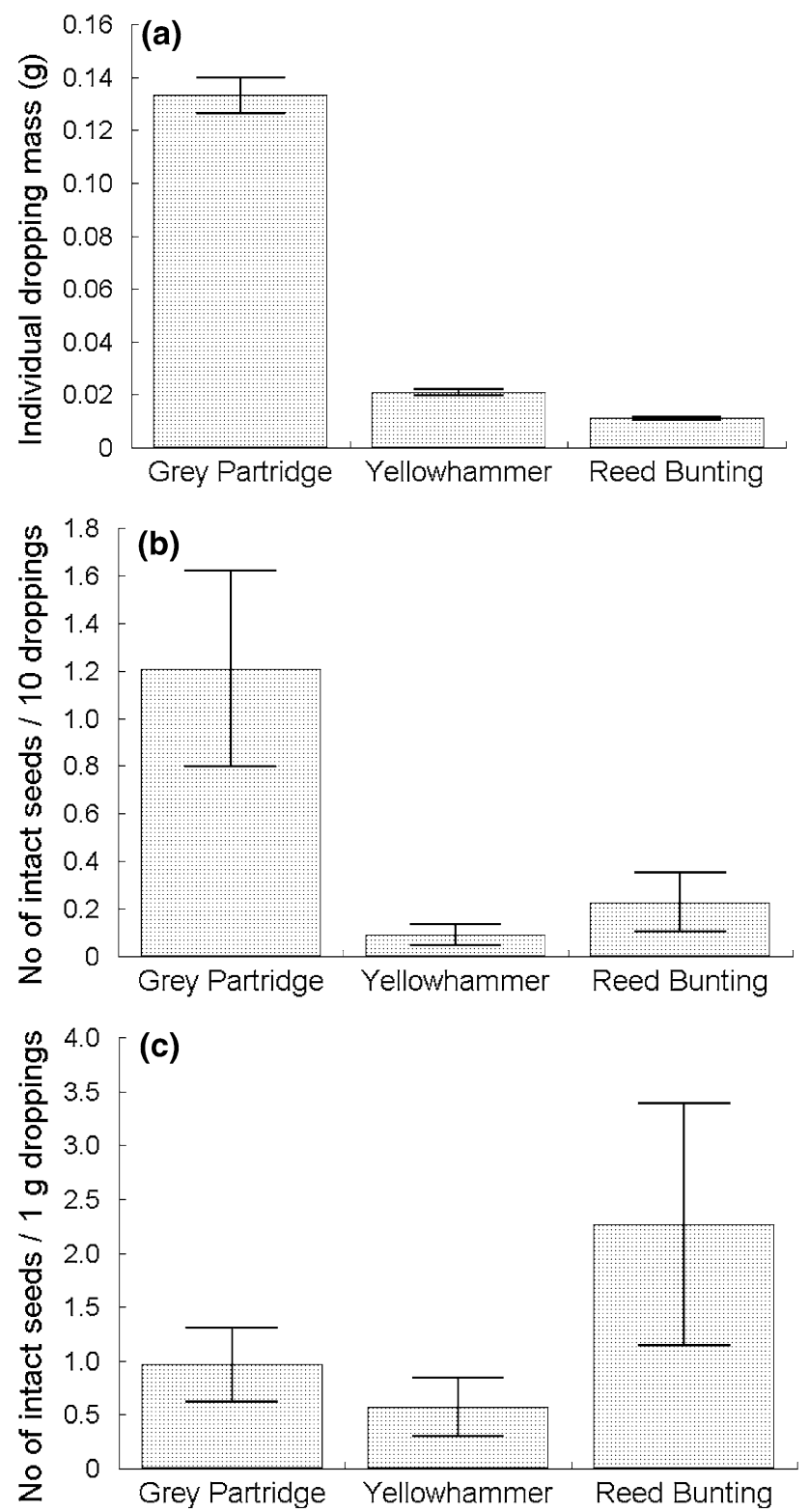

Fig. 1 Comparison of mean ( \pm 1 SE) dropping mass (a), number of intact seeds per 10 droppings (b) and number of intact seeds per $1 \mathrm{~g}$ of droppings (c) in three species of seed predators: Grey Partridge (36 samples/1162 droppings), Yellowhammer (26/624) and Reed Bunting (17/999)

The average number of intact seeds per ten droppings was the highest for Grey Partridge, less for Reed Bunting and the least for Yellowhammer (Fig. 1b). Furthermore, comparison of the average number of intact seeds per ten droppings among the target species showed significant differences between Grey Partridge and Reed Bunting (GLM: Wald $\chi_{(1)}^{2}=9.90, p=0.0016$ ) and between Grey Partridge and Yellowhammer (Wald $\chi_{(1)}^{2}=15.07$, $p=0.0001)$. There was no difference between Reed Bunting and Yellowhammer in this respect (GLM: Wald $\chi_{(1)}^{2}=1.19, p=0.274$ ) (Fig. 1b). Reed Bunting droppings from meadows and wetlands (30\% of all the droppings of this species) contained disproportionately more (83\% of all the droppings) intact seeds than the faecal samples collected from this species in other habitat types (chisquared goodness-of-fit test with Yates' correction: $d f=1$, $\chi^{2}=5.67, p=0.018$; Appendix Table 3).

The number of intact seeds per $1 \mathrm{~g}$ of droppings was the highest for Reed Bunting, followed by Grey Partridge and Yellowhammer (Fig. 1c). Comparison of the average number of intact seeds per $1 \mathrm{~g}$ of droppings between the target species showed significant differences between Grey Partridge and Reed Bunting (GLM: Wald $\chi_{(1)}^{2}=13.28$, $p=0.0003)$ and between Reed Bunting and Yellowhammer (Wald $\left.\chi_{(1)}^{2}=20.23, p<0.0001\right)$.

The probability of recovering at least one intact seed in a faecal sample of both buntings $(n=46)$ and Grey Partridge $(n=36)$ was not related to the number of droppings in a sample (logistic regression model: $\chi^{2}=1.08$ and $0.913, d f=1, p=0.226$ and 0.340 ; for the two bunting species and Grey Partridges respectively) or to the total weight of droppings in a sample (logistic regression model: $\chi^{2}=0.02$ and $2.07, d f=1, p=0.963$ and 0.150 respectively). The number of intact seeds was not correlated with either the total number or the total weight (both logtransformed) of droppings in a faecal sample of the two bunting species (GLM: $R^{2}=0.05$ and 0.0001 , $F_{1,41}=2.56$ and $0.002, p=0.141$ and 0.967$)$, but for Grey Partridge this (positive) relationship was significant $\left(R^{2}=0.146\right.$ and $0.207, F_{1,34}=5.80$ and 8.83, $p=0.021$ and 0.005$)$. By including faecal samples of all three seed predators $(N=79)$ we found that both the number of intact seeds (GLM: $\left.R^{2}=0.277, F_{3,75}=9.56, p<0.0001\right)$ and the probability of recovering at least one intact seed (logistic regression model: $\chi^{2}=4.85, p=0.026$ ) were positively related to the total weight of droppings in a sample.

DCA analysis revealed considerable differences in dietary composition among the three target species and a poor association between habitat type and the number of seeds in the faecal samples. These findings indicate that seed dispersal by granivorous birds occurs with a similar intensity in different land-cover types (Fig. 2). Only Reed Bunting droppings from meadows and wetlands $(30 \%$ of all the droppings of this species) contained disproportionately more (83\% of all the droppings) intact seeds than faecal samples collected in other habitat types (chi-squared goodness-of-fit test with Yates' correction: $d f=1$, $\chi^{2}=5.67, p=0.018$; Appendix Table 3).

The number of intact seeds in faecal samples was positively correlated with the abundance of seed shells in droppings only in the case of Grey Partridge (Table 2). We also found that the seed-dominated diet of many taxa 
Table 1 Seed pool found in faecal samples of Grey Partridge (36 samples), Reed Bunting (17 samples) and Yellowhammer (26 samples)

\begin{tabular}{|c|c|c|c|c|c|c|c|}
\hline \multirow[t]{2}{*}{ Plant species (live cycle) ${ }^{\mathrm{a}}$ [habitat] } & \multirow{2}{*}{$\begin{array}{l}\text { Dispersal } \\
\text { mode }^{\mathrm{b}}\end{array}$} & \multirow[t]{2}{*}{ Plant family } & \multicolumn{3}{|c|}{ Number of intact seeds (damaged seeds) } & \multicolumn{2}{|c|}{ Seed characteristics ${ }^{\mathrm{c}}$} \\
\hline & & & $\begin{array}{l}\text { Grey Partridge } \\
(n=36)\end{array}$ & $\begin{array}{l}\text { Yellowhammer } \\
(n=26)\end{array}$ & $\begin{array}{l}\text { Reed Bunting } \\
(n=17)\end{array}$ & $\begin{array}{l}\text { Seed } \\
\text { mass (mg) }\end{array}$ & $\begin{array}{l}\text { Seed } \\
\text { shape }\end{array}$ \\
\hline Capsella bursa-pastroris (A) [a] & A & Brassicaceae & $87(2)$ & 2 & 1 & 0.79 & 0.09 \\
\hline Amaranthus retroflexus (A) [a] & $\mathrm{B}^{*}$ & Amaranthaceae & $51(41)$ & - & 1 & 0.49 & 0.03 \\
\hline Chenopodium album (A) [a] & $\mathrm{B}$ & Chenopodiaceae & $23(14)$ & - & - & 0.67 & 0.03 \\
\hline Gypsophila muralis (A) [a] & $\mathrm{A}^{*}$ & Caryophyllaceae & 13 & - & - & 0.03 & 0.02 \\
\hline Stellaria media (A) $[\mathrm{a}]$ & B & Caryophyllaceae & 6 & - & - & 0.39 & 0.04 \\
\hline Artemisia vulgaris $(\mathrm{P})[\mathrm{a} / \mathrm{r}]$ & B & Asteraceae & 2 & - & - & 0.15 & 0.12 \\
\hline Phleum pratense $(\mathrm{P})[\mathrm{m}]$ & Ep & Poaceae & 2 & - & - & 0.45 & 0.05 \\
\hline Polygonum lapathifolium (A) [a/r] & $\mathrm{B}$ & Polygonaceae & 2 & - & - & 2.25 & 0.05 \\
\hline Echinochloa crus-galli (A) [a] & Ep* & Poaceae & 1 & 2 & - & 2.41 & 0.16 \\
\hline Galinsoga parviflora/ciliata (A) [a] & $\mathrm{A}^{*}$ & Asteraceae & 1 & - & - & $0.19 / 0.19$ & $0.08 / 0.12$ \\
\hline Juncus sp. ${ }^{\mathrm{d}}$ (A) [m/a] & Ep & Juncaceae & 1 & - & 1 & 0.02 & 0.03 \\
\hline Plantago major $(\mathrm{B} / \mathrm{P})[\mathrm{m} / \mathrm{a}]$ & Ep & Plantaginaceae & 1 & - & - & 0.24 & 0.09 \\
\hline Polygonum aviculare (A) $[\mathrm{a} / \mathrm{r}]$ & $\mathrm{B}$ & Polygonaceae & 1 & $3(2)$ & - & 1.57 & 0.05 \\
\hline Rumex crispus $(\mathrm{P})[\mathrm{m} / \mathrm{a}]$ & $\mathrm{B}$ & Polygonaceae & 1 & - & - & 2.13 & 0.03 \\
\hline Urtica dioica $(\mathrm{P})[\mathrm{r}]$ & Ep & Urticaceae & 1 & - & $7(5)$ & 0.11 & 0.08 \\
\hline Chenopodium hybridum (A) [a] & $\mathrm{B}$ & Chenopodiaceae & 1 & - & - & 1.41 & 0.05 \\
\hline Fallopia convolvulus (A) [a] & B & Polygonaceae & 1 & - & - & 5.02 & 0.04 \\
\hline Leonurus cardiaca (A) [r] & Ep* & Lamiaceae & 1 & - & - & 0.98 & 0.08 \\
\hline Роа аппиа $[\mathrm{r} / \mathrm{m}]$ & $\mathrm{B}$ & Poaceae & 1 & - & - & 0.24 & 0.12 \\
\hline Senecio sp. ${ }^{\mathrm{e}}$ (A) $[\mathrm{a} / \mathrm{r}]$ & A & Asteraceae & 1 & - & - & 0.27 & 0.17 \\
\hline Chenopodium sp. ${ }^{\mathrm{f}}$ (A) [a] & $\mathrm{B}^{*}$ & Chenopodiaceae & - & - & $2(1)$ & 0.19 & 0.05 \\
\hline Lysimachia $\mathrm{sp.}^{\mathrm{g}}(\mathrm{P})[\mathrm{w}]$ & $\mathrm{H}$ & Primulaceae & - & - & 1 & 0.31 & 0.05 \\
\hline Total & & & $198(57)$ & $7(2)$ & $13(6)$ & - & - \\
\hline
\end{tabular}

${ }^{a}$ Life cycle of plants: annual (A), biennial (B), perennial (P); habitat type: arable fields [a], ruderal [r], meadows [m], wetland/wet meadow [w]

b Dispersal mode according to Grime et al. (1996), if the species was absent there (*) dispersal mode was classified on the base of external adaptations of diaspores: $A$ anemochory (dispersed by wind, with wings or plumes, also the smallest seeds with no dispersal adaptations), $B$ barochory (dispersed by gravity), Ep epizoochory (dispersed by adhesion, with hooks, hairs or awns or adhesive through the secretion of mucilage), $H$ hydrochory (dispersed by water)

${ }^{c}$ Seed mass (mean value for one-seeded generative dispersule) and data to calculate seed shape index according to LEDA Traitbase (Kleyer et al. 2008)

d Calculations for Juncus bufonius

e Calculation for Senecio vulgaris

${ }^{\mathrm{f}}$ Calculation for Chenopodium glaucum

g Calculation for Lysimachia vulgaris

increases the number of seeds dispersed (Spearman rank correlation coefficient between seed number and number of wild taxa present in samples, $r_{\mathrm{s}}=0.362, p<0.01$, $N=79$ ).

\section{Discussion}

Our findings showed that the three species of granivorous birds studied here disperse intact seeds of dry-fruited species of several plant families. All the seeds were small $(<3 \mathrm{mg})$ with a compact shape (seed shape $<0.14)$. The majority of seeds found in the droppings had no external adaptations to dispersal (barochores or very small anemochores). Our results confirm the findings on seed features (low mass and compact shape) that facilitate their passage through the digestive tract of mammalian herbivores or large omnivorous birds (Janzen 1984; Pakeman et al. 2002; Bruun and Poschlod 2006; Calviño-Cancela et al. 2006). One needs to realise that only a small fraction of seeds consumed by granivorous birds remain undamaged after passage through the digestive tract (we calculated this as $0.3 \%$ of Amaranthus retroflexus seeds consumed by Grey Partridge) and only $17 \%$ of recovered seeds germinated (however, the germination tests of these seeds were performed nearly 3 years after the faeces had been collected; 


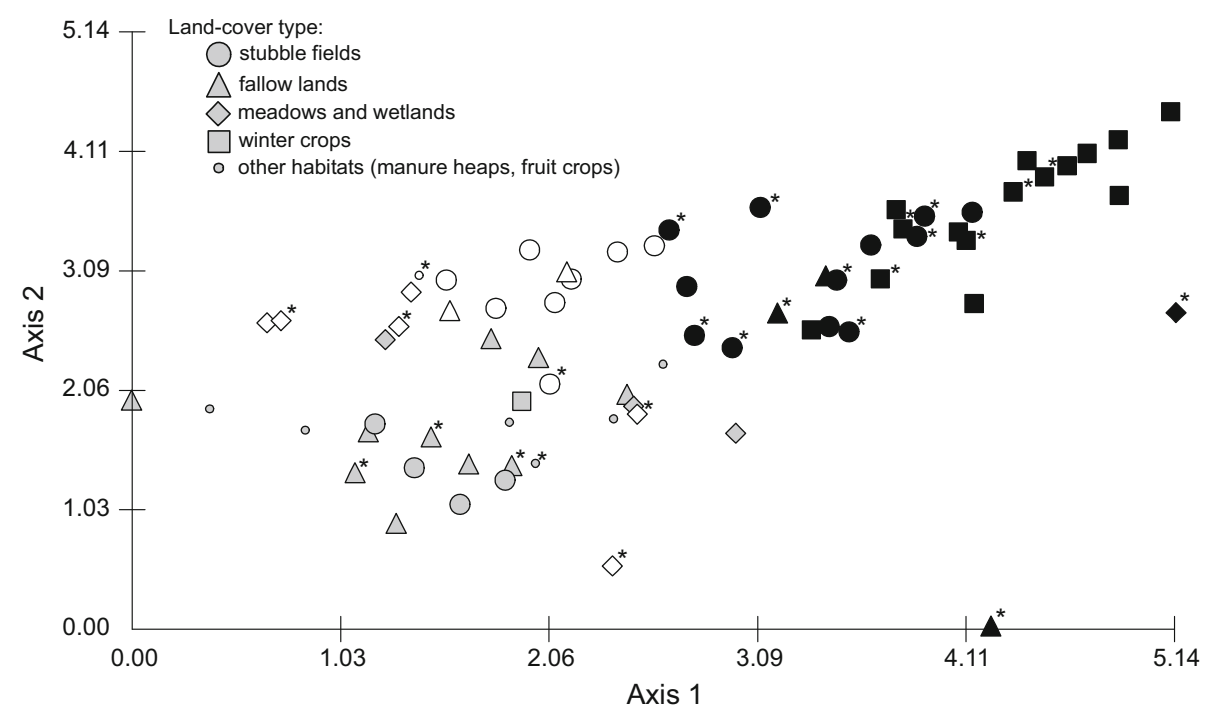

Fig. 2 Results of the DCA analysis of Grey Partridge (black), Yellowhammer (grey) and Reed Bunting (white symbols) based on dietary composition (see Appendix Table 4 for details). Samples with seeds marked with an asterisk. Eigenvalues: axis 1 0.742; axis 2 0.625; cumulative percentage variance: axis 1: 11.5; axis 2 21.1. Statistically significant Spearman rank correlation coefficients $\left(r_{\mathrm{s}}\right)$ between faecal sample characteristics and axis 1 (i) abundance of dietary variables: leaves $r_{\mathrm{s}}=0.870, \quad p<0.0001$; seed shells $r_{\mathrm{s}}=-0.567, \quad p<0.0001$; cereal grain fragments $r_{\mathrm{s}}=-0.344$, $p<0.01$; husks of wild grasses $-0.407, p<0.001$; animal prey

Table 2 Spearman rank correlation coefficients between the number of intact seeds per $1 \mathrm{~g}$ of droppings and the proportion of five major food categories (determined in four abundance classes: $0-3$; see Appendix Table 3) in the diet of three granivorous birds

\begin{tabular}{llll}
\hline Food category & $\begin{array}{l}\text { Grey Partridge } \\
(n=36)\end{array}$ & $\begin{array}{l}\text { Yellowhammer } \\
(n=26)\end{array}$ & $\begin{array}{l}\text { Reed Bunting } \\
(n=17)\end{array}$ \\
\hline Leaves & -0.291 & 0.116 & - \\
Seed shell & $0.563^{* * *}$ & 0.220 & -0.130 \\
$\begin{array}{c}\text { Cereal grain } \\
\text { Husks of wild } \\
\text { grasses }\end{array}$ & 0.030 & 0.061 & 0.000 \\
$\begin{array}{c}\text { Animal prey } \\
\text { items }\end{array}$ & - & -0.025 & 0.275 \\
& & -0.175 & 0.252
\end{tabular}

Asterisks denote the significance level: $* * * p<0.001$

cf. Orłowski and Czarnecka 2009). Our earlier studies and germination tests of seeds found in the faecal samples of Grey Partridge (including seeds recovered from the Grey Partridge droppings analysed in this study, Orłowski and Czarnecka 2007; Orłowski et al. 2013), Eurasian Blackbird Turdus merula (Czarnecka et al. 2012) and in pellets of the omnivorous Rook Corvus frugilegus (Czarnecka et al. 2010, 2013a, b) also demonstrated that seeds of dry-fruited species were able to germinate (20 and $15 \%$ of seeds found in the droppings of Grey Partridge and Eurasian Blackbird respectively, $34 \%$ in Rook pellets; the particular items $r_{\mathrm{s}}=-0.420, p<0.001$; number of plant species other than cereals in the diet $r_{\mathrm{s}}=-0.496, p<0.0001$ (ii) mean weight of one dropping $r_{\mathrm{s}}=0.739, p<0.0001$; axis 2 : (i) abundance of dietary variables: leaves $r_{\mathrm{s}}=0.635, p<0.0001$; seed shells $r_{\mathrm{s}}=-0.400$, $p<0.001$; cereal grain fragments $r_{\mathrm{s}}=-0.410, p<0.001$; husks of wild grasses $-0.411, p<0.001$; number of plant species other than cereals in the diet $r_{\mathrm{s}}=-0.444, p<0.0001$ (ii) mean weight of one dropping $r_{\mathrm{s}}=0.528, p<0.0001$. The number of seeds found in a faecal sample was not significantly correlated with any axis

percentage of germinating seeds depended on the plant species). Similarly, Holmes and Froud-Williams (2001) demonstrated that small-seeded plants (such as Stellaria media, found in our sample, too; cf. Table 1) can readily germinate from faecal samples of Chaffinch Fringilla coelebs, a small granivorous bird.

Importantly, even the small number of seeds dispersed by granivorous and omnivorous birds cannot be ignored, since just a small proportion (i.e., $0.001 \%$ ) of seeds moving (especially over long distances) can significantly increase predicted plant migration rates (Higgins and Richardson 1999). If we assume that birds are among the most mobile links in all types of ecosystems (Sekercioglu 2006), we believe that all seed dispersal events with birds as vectors require attention. It is worth emphasising that the probability of seed germination and seedling establishment in the case of scatter-hoarding in temperate forests with small rodents as dispersal vectors is much higher, achieving values from 0.6 to $3.2 \%$, depending on the tree species (Zhang et al. 2005). The survival of acorns in jay-made caches has rarely been quantified (den Ouden et al. 2005), but in an experiment by Gomez et al. (2003) similar values were obtained: $<4 \%$ of experimentally cached acorns survived.

Among the three bird species studied here, the quantity of intact seeds recovered from droppings was the largest 
for Grey Partridge. On the other hand, the number of intact seeds per $1 \mathrm{~g}$ of droppings was, rather surprisingly, the highest for Reed Bunting (the species with the lightest droppings), especially in samples from meadows and wetlands, which also contain fragments of invertebrates. Our findings revealed a relationship between the number of intact seeds in the droppings of the three target species and the proportion of seeds in the birds' diet and the dietary diversity. The difference in the number of intact seeds per $1 \mathrm{~g}$ of droppings between the two buntings can be explained by comparing the composition of their diets: Reed Bunting has a higher frequency of weed seeds and a lower frequency of cereal grains (which in principle are larger than weed seeds) in its diet (Appendix Table 3). Similarly, there appear to be a relatively higher number of intact seeds in faecal samples of Grey Partridge from stubble fields, which provided a staple diet of weed seeds (Appendix Table 3). In general, therefore, these findings appear to confirm that smaller (and/or more rounded) seeds with a hard shell have a greater probability of escaping destruction during gut passage (Janzen 1984; Malo and Suarez 1995; Malo et al. 2000; Pakeman et al. 2002; Bruun and Poschlod 2006). On the other hand, the observed differences in the number of intact seeds recovered from droppings of the three target species could also have arisen from differences in the morphology or physiological features of the digestive tracts of these birds (sensu Herrera 1984).

The significant relationship between the number of intact seeds and the total weight of droppings found for all three species and solely for Grey Partridge in a separate analysis (with rather large droppings) suggests that the treatment of seeds in the digestive tract of all three species is a function of the volume of seeds consumed (excluding cereal grains, which are completely digested) and stomach size, which is proportional to total body mass (White and Stiles 1990). First, the presence of intact seeds is probably an effect of limited digestion, which in turn is a consequence of the intake of a large volume of seeds, of which just a small part remains undigested (=a digestive bottleneck; Kersten and Visser 1996). Second, this effect may be modified by the inclusion of some items of different digestibility (or alternatively small amounts of seeds ingested along with other food items), e.g., some invertebrates (as in the case of Reed Bunting's mixed diet) or leaves, which was generally negatively correlated with the number of intact seeds in Grey Partridge faecal samples (cf. Orłowski and Czarnecka 2013 for a more detailed dietary analysis). The differences in food availability among different habitat types (e.g., more weed seeds are available in stubble fields than in winter crops) thus appear to affect the number of intact seeds in bird faeces.

In summary, it should be stressed that Grey Partridge and the two buntings are rather poor seed dispersers; they are basically seed consumers ( $\approx$ seed predators), especially if we note the low overall number and low frequency of intact seeds found in their faeces. Viable seeds were found in 1.1-1.3\% of bunting droppings, which is a very low figure compared with the results obtained for frugivorous species. Between 24 and $77 \%$ of the droppings of Nearctic warblers, manakins, tanagers, thrushes and flickers contained plant seeds (Loiselle 1990; White and Stiles 1990). However, in the context of the seed diet and migratory behaviour of some species of gamebirds and buntings, even the small fraction of plant propagules that escape digestion can be an important pathway to the colonisation of new and distant sites (Nogales et al. 2012). Here we stress that nonstandard seed dispersal by birds, especially in the case of plant species without any well-developed dispersal adaptations, is a relatively frequent yet under-appreciated phenomenon with potential ecological implications for plant colonisation. However, the ultimate elucidation of this process is extremely difficult and would require the examination of large sets of faeces. A further study exploring relationships between the digestibility of various dietary components would be especially advisable in order to assess the potential role of seed-eating and omnivorous birds in aiding the long-distance dispersal of plants.

Acknowledgments We are grateful to Prof. Doug Levey and anonymous reviewers for their constructive comments on our work. We appreciate the improvements in English usage made by Peter Lowther through the Association of Field Ornithologists programme of editorial assistance and Peter Senn.

Open Access This article is distributed under the terms of the Creative Commons Attribution 4.0 International License (http:// creativecommons.org/licenses/by/4.0/), which permits unrestricted use, distribution, and reproduction in any medium, provided you give appropriate credit to the original author(s) and the source, provide a link to the Creative Commons license, and indicate if changes were made.

\section{Appendix}

See Tables 3 and 4. 


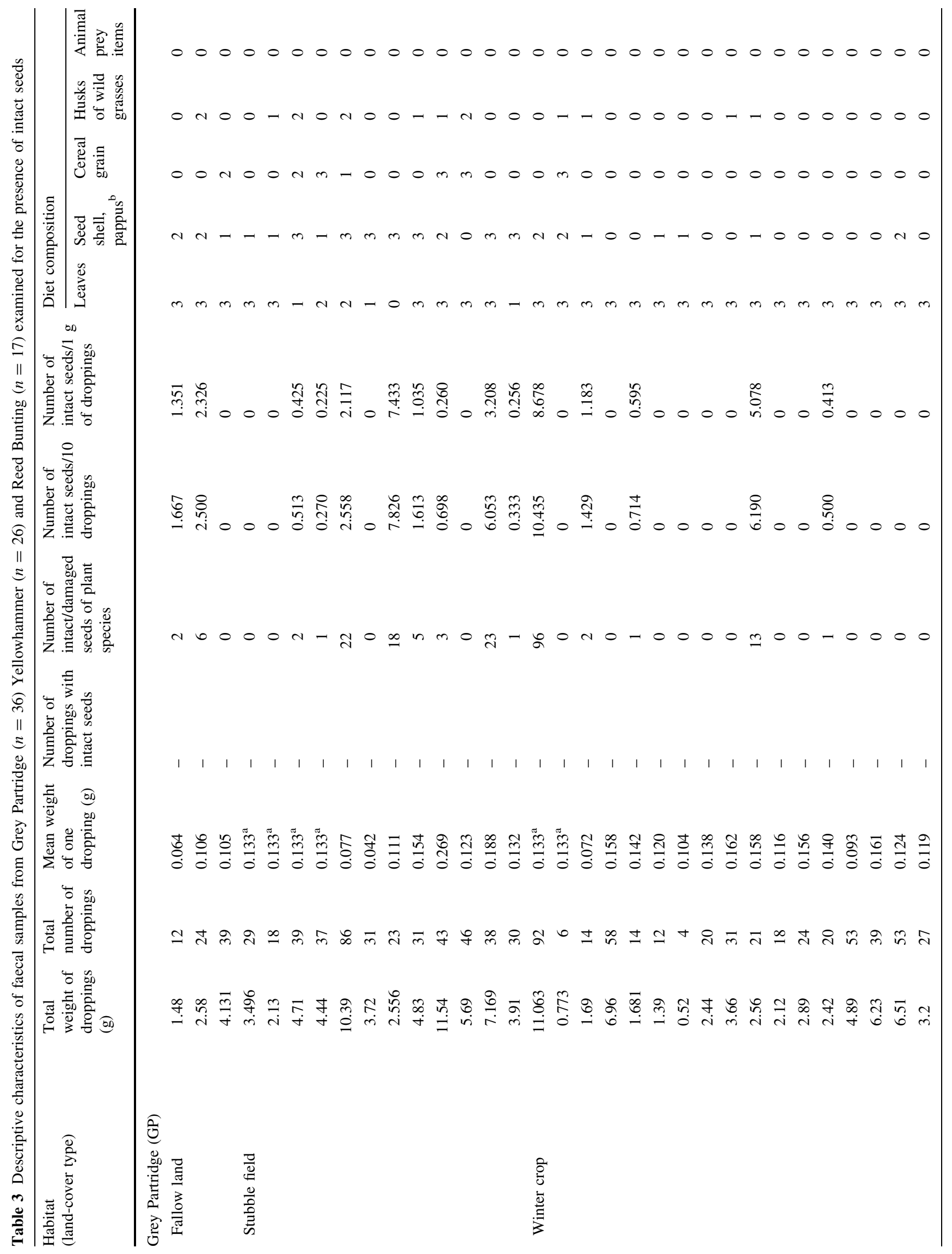




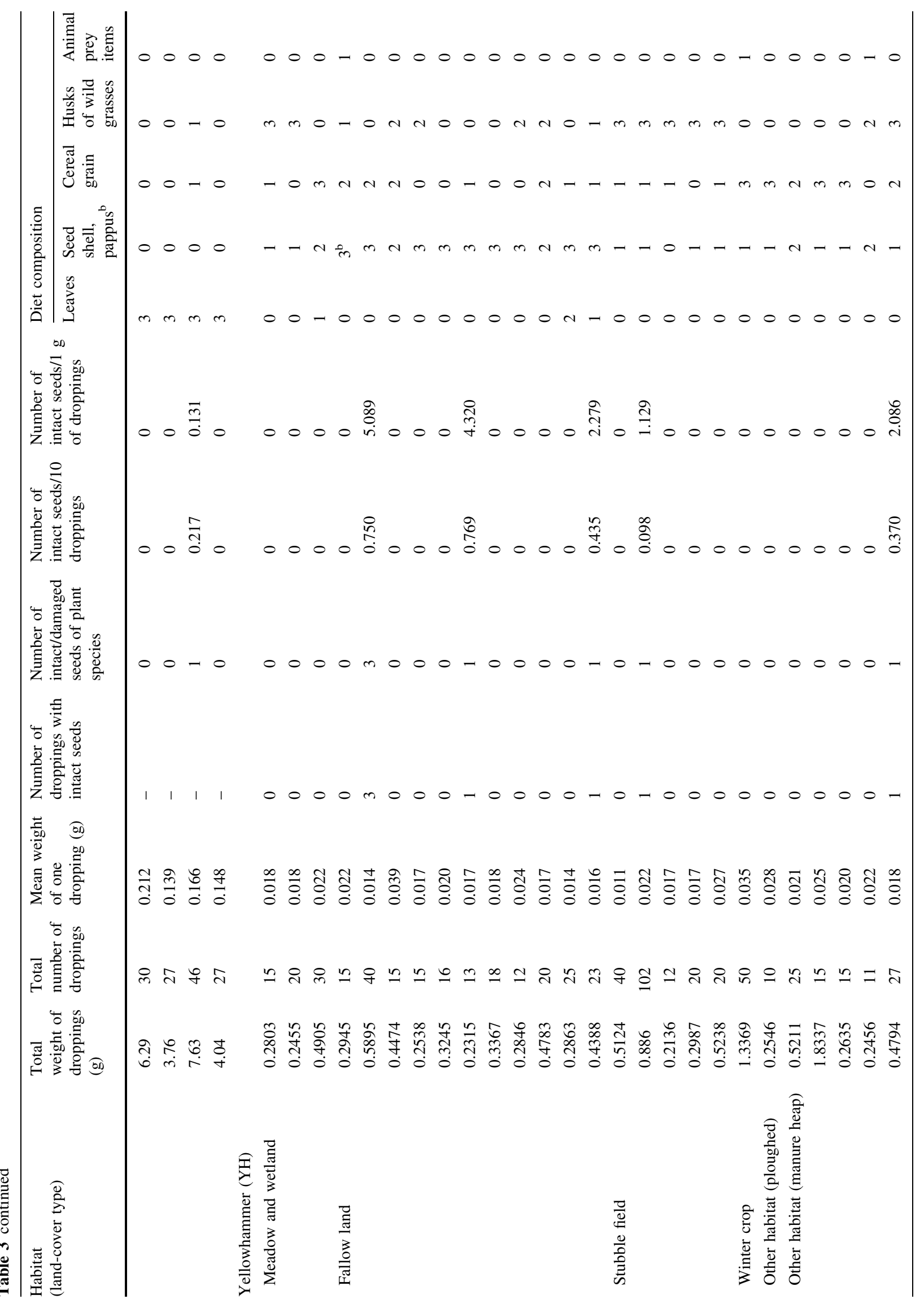




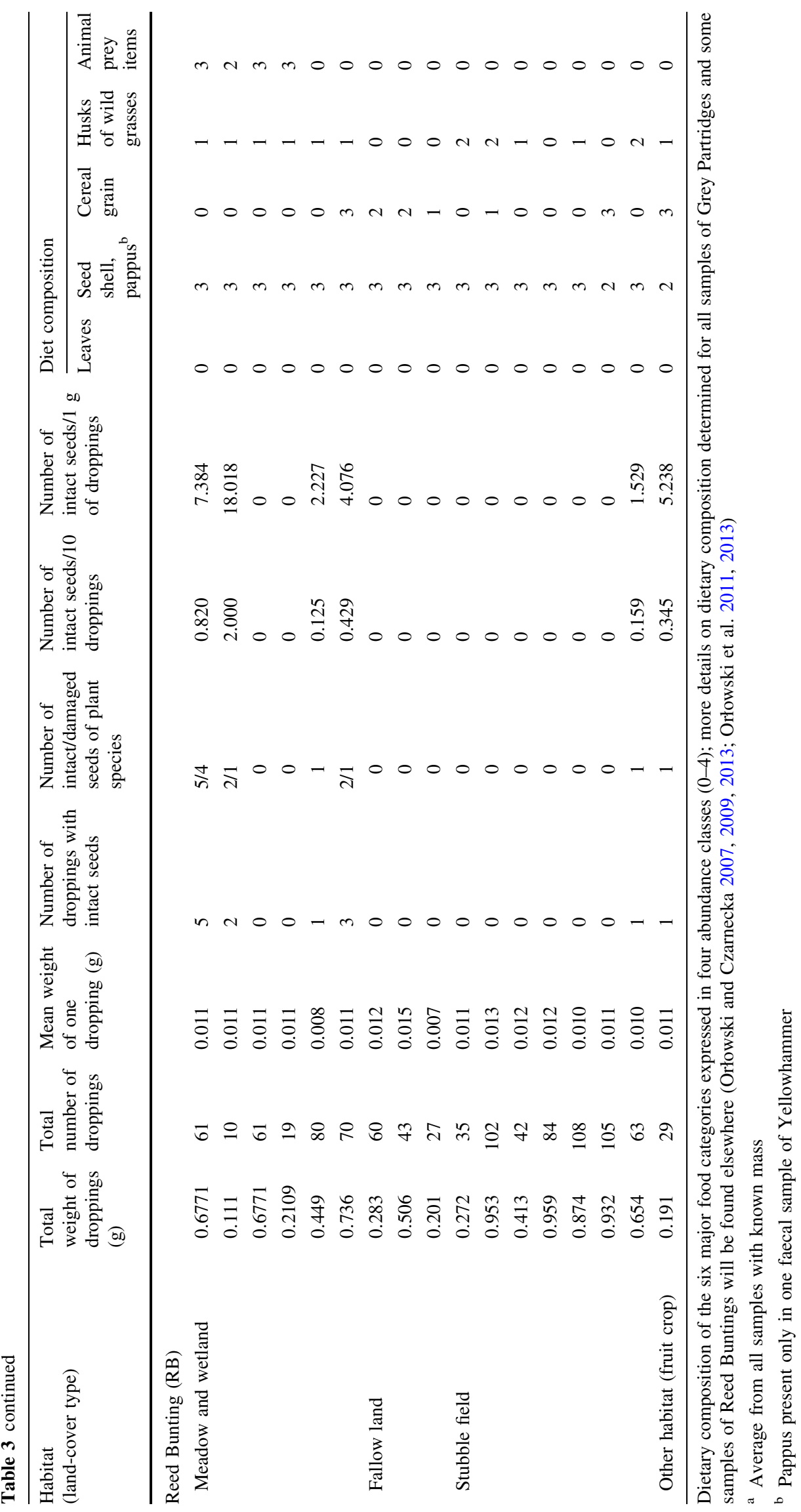


Table 4 Variables used in detrended correspondence analysis (DCA)

\begin{tabular}{|c|c|c|c|}
\hline \multirow[t]{2}{*}{ Variable } & \multicolumn{3}{|c|}{ Bird species } \\
\hline & $\begin{array}{l}\text { Grey } \\
\text { Partridge }\end{array}$ & Yellowhammer & $\begin{array}{l}\text { Reed } \\
\text { Bunting }\end{array}$ \\
\hline
\end{tabular}

Leaves

Artemisia vulgari

Bidens sp.

Poaceae

Dicotyledonous taxa

Other unidentified leaves

Seed shell fragments

\begin{tabular}{|c|c|c|c|}
\hline Alisma plantago-aquatica & & & + \\
\hline Amaranthus retroflexus & + & & + \\
\hline Capsella bursa-pastoris & + & & \\
\hline Chenopodium hybridum & + & & \\
\hline Leonurus cardiaca & + & & \\
\hline Polygonum aviculare & + & & + \\
\hline Stellaria media & + & & \\
\hline Taraxacum officinale & + & & \\
\hline Urtica dioica & & & + \\
\hline Chenopodium sp. & + & + & + \\
\hline Galinsoga parviflora/ciliata & + & & \\
\hline Bidens sp. & & & + \\
\hline Polygonum sp. & + & & + \\
\hline Veronica sp. & + & & \\
\hline Grains fragments & & & \\
\hline Triticum aestivum & + & + & + \\
\hline Other cereals & & + & + \\
\hline Elymus repens & & + & \\
\hline Other Poaceae & + & + & \\
\hline Husks of grasses & & & \\
\hline Echinochloa crus-galli & + & + & + \\
\hline Digitaria sp. & & + & \\
\hline Setaria sp. & + & + & + \\
\hline Other Poaceae & + & + & \\
\hline Dther plant items & & & \\
\hline Compositae pappus & & + & \\
\hline Juncus sp. fruit fragments & + & & \\
\hline Animal prey items & + & + & \\
\hline
\end{tabular}

The following scale of item abundance in droppings was used during the analysis of each sample (study site, $N=79$ ): 1 , sporadic items; 2 , items of medium abundance; 3 , dominant items

+ Indicates the presence of a variable in the droppings of one particular bird species

\section{References}

Bojňanský V, Fargašová A (2007) Atlas of seeds and fruits of Central and East-European flora. The Carpathian Mountains Region. Springer, Dordrecht
Bradford MG, Westcott DA (2011) Predation of cassowary dispersed seeds: is the cassowary an effective disperser? Integr Zool 6:168-177

Bruun HH, Poschlod P (2006) Why are small seeds dispersed through animal guts: large numbers or seed size per se? Oikos 113:402-411

Buddenhagen C, Jewell KJ (2006) Invasive plant seed viability after processing by some endemic Galapagos birds. Ornithol Neotrop 17:73-80

Butler SJ, Mattison E, Glithero N, Robinson L, Atkinson P, Gillings S, Vickery J, Norris K (2010) Resource availability and the persistence of seed-eating bird populations in agricultural landscapes: a mechanistic modelling approach. J Appl Ecol 47:67-75

Calviño-Cancela M, Dunn RR, van Etten E, Lamont B (2006) Emus as non-standard seed dispersers and their potential for longdistance dispersal. Ecography 29:632-640

Cappers RT, Bekker R, Jans J (2006) Digitale Zadenatlas van Nederland. Barkuis Publishing io\& Groningen University Library, Groningen

Cipollini ML, Levey DJ (1997) Why are some fruits toxic? Glycoalaloids in Solanum and fruit choice by vertebrates. Ecology 78:782-798

Cramp S (1998) The complete birds of the Western Palearctic on CDROM. Oxford Univ Press, Oxford

Czarnecka J, Kitowski I (2010) Seed dispersal by the Rook Corvus frugilegus $\mathrm{L}$. in agricultural landscape-mechanisms and ecological importance. Pol J Ecol 58:511-523

Czarnecka J, Kitowski I (2013) Rook spring seed dispersal in the agricultural landscape-Frugivory, granivory or accidental transport? Folia Geobot 48:55-73

Czarnecka J, Orłowski G, Karg J (2012) Endozoochorous dispersal of alien and native plants by two palearctic avian frugivores with special emphasis on invasive giant goldenrod Solidago gigantean. Cent Eur J Biol 7:895-901

Czarnecka J, Kitowski I, Sugier P, Mirski P, Krupiński D, Pitucha G (2013) Seed dispersal in urban green space-does the rook Corvus frugilegus L. contribute to urban flora homogenization? Urban For Urban Green 12:359-366

D'hondt B, Hoffmann M (2011) A reassessment of the role of simple seed traits in mortality following herbivore ingestion. Plant Biol 13:118-124

Den Ouden J, Jansen PA, Smit R (2005) Jays, Mice and Oaks: predation and dispersal of Quercus robur and Q. petrea in NothWestern Europe. In: Forget PM, Lambert JE, Hulme PE, Vander Wall SB (eds) Seed fate. Predation, dispersal and seedling establishment. CABI Publishing, UK, pp 223-239

Evans DM, Pocock M, Brooks J, Memmott J (2011) Seeds in farmland food-webs: resource importance, distribution and the impacts of farm management. Biol Conserv 144:2941-2950

Gillespie RG, Baldwin B, Waters J, Fraser C, Nikula R, Roderick G (2012) Long-distance dispersal: a framework for hypothesis testing. Trends Ecol Evol 27:47-56

Grime JP, Hodgson JG, Hunt R (1996) Comparative plant ecology: a functional approach to common British species. Chapman and Hall, London

Gomez JM, Garcia D, Zamora R (2003) Impact of vertebrate acornand seedling-predators on a Mediterranean Quercus pyrenaica forest. For Ecol Manage 180:125-134

Guerrero AM, Tye A (2009) Darwin's Finches as seed predators and dispersers. Wilson J Ornithol 121:752-764

Heleno RH, Ross G, Everard A, Memmott J, Ramos J (2010) The role of avian seed predators as seed dispersers. Ibis 153:199-203

Heleno RH, Olesen JM, Nogales M, Vargas P, Traveset A (2013) Seed dispersal networks in the Galapagos and the consequences of alien plant invasions. Proc R Soc B 280:2012-2112 
Herrera CM (1984) Adaptation to frugivory of Mediterranean avian seed dispersers. Ecology 65:609-617

Higgins SI, Richardson DM (1999) Predicting migration rates in changing world: the role of long distance dispersal. Am Nat 153:464-475

Holland JM, Hutchinson M, Smith B, Aebischer N (2006) A review of invertebrates and seed-bearing plants as food for farmland birds in Europe. Ann Appl Biol 148:49-71

Holmes RJ, Froud-Williams RJ (2001) The predation and dispersal of weed seeds by birds. The BCPC Conference: Weeds, 2001, vol. 1 and 2, Brighton, UK, pp 333-336

Holmes RJ, Froud-Williams RJ (2005) Post dispersal weed seed predation by avian and non-avian predators. Agric Ecos Environ 105:23-37

Hulme PE (2002) Seed-eaters: seed, dispersal, destruction and Demography. In: Levey DJ, Silva W, Galetti M (eds) Seed dispersal and frugivory: ecology, evolution and conservation. CABI Publishing, Wallingford, pp 257-274

Janzen DH (1984) Dispersal of small seeds by big herbivores: foliage is the fruit. Am Nat 123:338-353

Kasprzykowski Z, Goławski A (2012) Habitat preferences of granivorous passerine birds wintering on farmland in eastern Poland. Bird Study 59:52-57

Kersten M, Visser W (1996) The rate of food processing in oystercatchers: food intake and energy expenditure constrained by digestive bottleneck. Funct Ecol 10:440-448

Kleyer M, Bekker R, Knevel I, Bakker J, Thompson K, Sonnenschein M, Poschold P, van Groenendael J, Klimeš L, Klimešova J, Klotz S, Rusch G, Hermy M, Adriaens D, Boedeltje G, Bossuyt B, Dannemann A, Endels P, Götzenberger L, Hodgson JG, Jackel AK, Kühn I, Kunzmann D, Ozinga WA, Römermann C, Stadler M, Schlegmilch J, Steendam HJ, Tackenberg O, Wilmann B, Cornelissen JHC, Eriksson O, Garnier E, Peco B (2008) The LEDA Traibase: a database of life-history traits of Northwest European flora. J Ecol 96:1266-1274

Kovach WL (ed) (2005) MVSP-A MultiVariate Statistical Package for Windows, ver. 3.1. Kovach Computing Services, Pentraeth

Lenda M, Skórka P, Knops JMH, Moroń D, Tworek S, Woyciechowski M (2012) Plant establishment and invasions: an increase in a seed disperser combined with land abandonment cause an invasion of non-native walnut in Europe. Proc R Soc B 279:1491-1497

Loiselle BA (1990) Seeds in droppings of tropical fruit eating birds: importance of considering seed composition. Oecologia 82:494-500

Malo JE, Suarez F (1995) Herbivorous mammals as seed dispersers in a Mediterranean dehesa. Oecologia 104:246-255

Malo JE, Jiménez B, Suarez F (2000) Herbivore dunging and endozoochorous seed deposition in a Mediterranean dehesa. J Range Manage 53:322-328

Marone L, Lopez de Casenave J, Cueto C (2000) Granivory in southern South American deserts: conceptual issues and current evidence. Bioscience 50:123-132

Moorcroft D, Whittingham M, Bradbury R, Wilson J (2002) The selection of stubble fields by wintering granivorous birds reflects vegetation cover and food abundance. J Appl Ecol 39:535-547

Nogales M, Heleno R, Traveset A, Vargas P (2012) Evidence for overlooked mechanisms of long-distance seed dispersal to and between oceanic islands. New Phytol 194:313-317

Norconk MA, Grafton BW, Conklin-Brittain NL (1998) Seed dispersal by neotropical seed predators. Am J Primatol 45:103-126

Orłowski G (2006) Cropland use by birds wintering in arable landscape in south-western Poland. Agr Ecos Environ 116:273-279

Orłowski G, Czarnecka J (2007) Winter diet of reed bunting Emberiza schoeniclus in fallow and stubble fields. Agr Ecos Environ 118:244-248
Orłowski G, Czarnecka J (2009) Granivory of birds and seed dispersal: viable seeds of Amaranthus retroflexus L. recovered from the droppings of the Grey Partridge Perdix perdix L. Pol J Ecol 57:191-196

Orłowski G, Czarnecka J (2013) Re-evaluation of the role of the grey partridge Perdix perdix as a disperser of arable weed seeds. J Ornithol 154:139-144

Orłowski G, Czarnecka J, Panek M (2011) Autumn-winter diet of Grey Partridges Perdix perdix in winter crops, stubble fields and fallows. Bird Study 58:473-486

Orłowski G, Czarnecka J, Karg J (2013) Substantial contribution of invertebrates to the diet of a winter seed-eater, the reed bunting Emberiza schoeniclus, wintering in a sewage farm in southwestern Poland. Biol J Linn Soc 108:429-433

Orłowski G, Czarnecka J, Goławski A (2014) Winter diet of Yellowhammers Emberiza citrinella on contemporary farmland: the different contribution of forbs, wild grasses and cereals in semi-natural and agricultural habitats. Bird Study 61:484-495

Pakeman RJ, Digneffe G, Small J (2002) Ecological correlates of endozoochory by herbivores. Funct Ecol 16:296-304

Panek M (2005) Demography of grey partridges Perdix perdix in Poland in the years 1991-2004: reasons of population decline. Eur J Wild Res 51:14-18

PECMBS (2011) Population Trends of Common European Breeding Birds 2011. CSO, Prague

Pinowski J, Wójcik Z (1968) Production of weeds in fields and degree to which their seeds are consumed by the Tree Sparrow (Passer montanus L.). Ekol Pol (B) 14:297-302

Robinson RA, Sutherland WJ (2000) The winter distribution of seedeating birds: habitat structure, seed density and seasonal depletion. Ecography 22:447-454

Roessler ES (1936) Viability of weed seeds after ingestion by California linnets. Condor 38:62-65

Schönswetter P, Elven R, Brochmann G (2008) Trans-atlantic dispersal and large-scale lack of genetic structure in the circumpolar, arctic-alpine sedge Carex bigelowii S. L. (Cyperaceae). Am J Botany 95:1006-1014

Schupp EW (1993) Quantity, quality and the effectiveness of seed dispersal by animals. Vegetatio 107(108):15-29

Schupp EW, Jordano P, Gómez J (2010) Seed dispersal effectiveness revisited: a conceptual review. New Phytol 188:335-353

Sekercioglu CH (2006) Increasing awareness of avian ecological function. Trends Ecol Evol 21:464-471

Statsoft (2007) Statistica $\bigodot$ (data analysis software system), version 7.1. Tulsa, USA

Thompson K, Band S, Hodgson J (1993) Seed size and shape predict persistence in soil. Funct Ecol 7:236-241

Vander Wall SB (1990) Food hoarding in animals. University of Chicago Press, Chicago

Vander Wall SB (2010) How plants manipulate the scatter-hoarding behaviour of seed dispersing animals. Phil Trans R Soc B 365:989-997

Wenny DG, DeVault T, Johnson M, Kelly D, Sekercioglu C, Tomback D, Whelan C (2011) The need to quantify ecosystem services provided by birds. Auk 128:1-14

White D, Stiles E (1990) Co-occurrences of foods in stomachs and feces of fruit-eating birds. Condor 92:291-303

Zhang ZB, Xiao ZS, Li HJ (2005) Impact of small rodents on tree seeds in temperate and subtropical forests. In: Forget PM, Lambert JE, Hulme PE, VanderWall SB (eds) Seed fate. Predation, Dispersal and Seedling Establishment. CABI Publishing, UK, pp 269-282

Zwolak R, Crone E (2011) Quantifying the outcome of plantgranivore interactions. Oikos 121:20-27 